International Journal of Agriculture, Environment and Bioresearch

Vol. 4, No. 06; 2019

ISSN: $2456-8643$

\title{
EVALUATION OF SHORT DURATION DROUGHT TOLERANT UPLAND RICE VARIETY SAHABHAGIDHAN IN GANJAM DISTRICT OF ODISHA
}

\author{
Kabita Mishra \\ Scientist (Agronomy), Krishi Vigyan Kendra, Ganjam-II, Berhampur \\ http://doi.org/10.35410/IJAEB.2019.4493
}

\begin{abstract}
A study was conducted in farmer's field through front line demonstrations during Kharif season of 2015 and 2016 in Ganjam district of Odisha to evaluate the short duration drought tolerant upland rice variety Sahabhagidhan. The results of demonstration showed that farmers could increase the productivity notably by switching over to improved variety Sahabhagidhan and adoption of improved production technology. From the front line demonstration, it was observed that rice variety Sahabhagidhan recorded higher grain yield $(32.9 \mathrm{q} / \mathrm{ha})$ as compared to farmers practice Khandagiri $(25.2 \mathrm{q} / \mathrm{ha})$. The increase in the demonstration yield over farmer's practices was 30 per cent with harvest index 47.4. The improved variety gave higher gross return of Rs. 50029 ha- 1 with a benefit cost ratio of 1.46 and additional net return of Rs.9626 ha-1 as compared to local check.
\end{abstract}

Keywords: Short duration variety, Rice, Front line demonstartion, Economics, Harvest Index.

\section{INTRODUCTION}

Rice is the most popular stable food in Asia. It is estimated that over $90 \%$ of rice is produced and consumed in Asia. Also, in many of the Asian counties, rice yield per hectare has doubled within the 20 years of the Green Revolution (Baker et al., 2007). This is mainly due to the adoption of high yielding rice varieties along with the increase in the cropping intensity and farm inputs (FAO, 2013). With varied geographical conditions suitable for the rice cultivation, Ganjam district in Odisha state of India boats of varied topographical soil condition ideally suited for the cultivation of cereal, cash crops, and horticultural and other plantation crops.

Developing drought tolerant rice cultivars is considered to be one of the most effective and economic approaches to ensuring food security(Verma and Srivastava, 2004). A large portion about $70 \%$ of area under rice in India is drought prone rainfed, but it has not been exploited to full potential due to lack of suitable drought tolerant or resistant varieties ( Kumar et al., 2012). There is hardly any scope to replace the rice crop considering the precipitation of less than $1500 \mathrm{~mm}$ rainfall during the monsoon season. However, multiple cropping system using short duration rice varieties and intensive input management may enhance the land use efficiency and increase the production level if sowing of rabi crops are made in time(Khanda et al., 2005). It is called Sahbhagi Dhan, which means "rice developed through collaboration" in Hindi (Reyes 2009). This name was given to it because the variety was tested under a collaborative project between IRRI and many Indian organizations. Sahabhagi Dhan has shown a yield advantage of 0.8 to 1 ton ha-1over other varieties under drought conditions (Yamano et al., 2013). Hence, there 
remains a scope to introduce a short duration high yielding rice variety in existing rice-based cropping system. If the farmers are able to harvest their kharif rice 25-30 days earlier than usual harvesting time then they could able to sow their next crop in time during rabi. The new improved technologies will eventually lead to the farmers to discontinue the old varieties and to adopt new variety. Similar results were reported by Sharma et al.(2011) .

However, there is a dearth of short duration varieties which will fit well into the reduced growing period brought about by the changing climatic and rainfall pattern. It has been reported that climate change is imminent and the world is already experiencing the extreme weather events threatening world food production (Wassmann et al. 2009; IPCC 2007).Global warming and climate change are predicted to have a major impact on rice production necessitating both adaption and mitigation strategies. Among the agricultural crops, rice is highly vulnerable to climatic extremes such as drought, unseasonal rains, flooding and high temperature stress. In the event of climate change, affected are mainly the poor farmers who lose their farm assets such as crops and potential land to the forces of nature. Farming works are highly susceptible to climatic shocks and failure due to myriad interplay of factors. Among the most important factors are the climatic and environmental factors such as temperature and rainfall as they directly affect agricultural productivity. Given the intrinsic nature of these risks, it is of paramount importance to develop various coping mechanisms to avoid or reduce the impact of climate-induced risks. One area to look at is to have climate resilient crop varieties and those which would fit into the altered growing conditions. According to the Food and Agriculture Organization (FAO, 2014), one of the major technological options for adapting to climate change is to grow short duration rice varieties that can escape drought or submergences. Therefore, introduction and evaluation of short duration rice varieties would be imperative both from the view point of climate change as well as from the perspective of rice double cropping in potential areas of the country

One of the objectives of modern breeders is to obtain varieties that could mature quickly and are insensitive to day length, thereby permitting more crops each year in the same land (Bagchi et al. 2012; Hazell P.R 2010). Thus, crop intensification could enhance the total farm productivity and production. While the short duration varieties could very easily escape harsh dry spells and provide a window of opportunity to be harvested within a short period of time, it will give added advantages to enhance production through double cropping. Growing a short duration variety has other global significance as well. Hasan (2014) reported that growing short duration rice is one of the most important ways of mitigating methane emission, a greenhouse gas that contributes to climate change. The traditional rice varieties take about 160-200 days (De Datta, 1981) to mature and are highly susceptible to climatic events. Improved short duration varieties could be harvested in about 110 to 130 days.Rice being a major food crop in the country, it should receive maximum priority for the research, investment and policy. It is going to be of immense importance to continue introduction and evaluation of rice varieties for yield potential, maturity duration, resistance to pests and diseases and grain quality. Therefore, the objective of this research is to evaluate and screen higher yielding short duration varieties

Keeping in view such problems and after detailed survey the KVK, Ganjam-II made an attempt with an objective to evaluate growth and yield parameters of newly released promising high yielding variety paddy cv. Sahabhagidhan through on farm testing for its suitability in the 
existing farming situation for substitution of old variety( Khandagiri) with higher productivity and income.

\section{MATERIALS AND METHODS}

The study was carried out through on farm testing during kharif season of 2015and 2016 at Padripalli, Sunathara, Padmabati, Hinjili village in Ganjam district . The district of Ganjam lies in two agro climatic zones i.e East \& South Eastern coastal plain zone and North Eastern Ghat Zone of Odisha extending from $18^{0} 13^{\prime} \mathrm{N}$ to $19^{0} 10^{\prime}$ North latitude to $82^{0} 5^{\prime}$ to $83^{0} 23^{\prime}$ East longitude. The Average Normal Rainfall of this district is $1276.2 \mathrm{~mm}$ and more than $75 \%$ of the precipitation is received over five months i.e. June- October .Agriculture is the primary occupation of inhabitants of this district. The maximum and minimum temperature of this district is $39^{\circ} \mathrm{C}$ and $18.9^{\circ} \mathrm{C}$ respectively Ten different farmers each having 0.2 hectare of land cultivated the HYV rice Manaswini with recommended package of practices. They were supplied with seed. Besides farmers practice of one old HYV rice Khandagiri was selected as local check.

The tested high yielding variety "Sahabhagi dhan" was released from CRRI in 2009 can be suitably directs sown or transplanted in rainfed upland ecosystem and tolerant to drought and is resistant to leaf blast, moderately resistant to brown spot, sheath rot, stem borer, leaf folder.. The crops were sown during 3rd week of June and harvested during 4th week of September. Observations on different growth and yield parameters were taken and economic analysis was done by calculating cost of cultivation, gross return, net return and $\mathrm{B}: \mathrm{C}$ ratio. Available soil nutrients as well as nutrient content were determined following the standard procedures (Jackson, 1973) .Water productivity (rain water productivity) was expressed as kilogram of rice yield obtained per millimeter of rain water received. Final crop yield (grain \& straw) were recorded and the gross return were calculated on the basis of prevailing market price of the produce. Harvest index is the relationship between economic yield and biological yield (Gardner et al.,1985). It was calculated by using the Following formula;

\section{Harvest index $(\%)=$ Economic yield \\ ------------- $\times 100$ \\ Biological yield}

The data were statistically analyzed applying the techniques of analysis of variance and the significance of different sources of variations were tested by error mean square of Fisher Snedecor's 'F' test at probability level 0.05 (Cochran and Cox, 1977). The data output were collected from both FLD plots as well as control plots and finally the extension gap, technology gap, technology index along with the benefits cost ratio were calculated (Samui et al., 2000) as below:

Technology gap $=$ Potential yield - Demonstration yield

Extension gap $=$ Demonstration yield - Farmers yield

Technology index $(\%)=$ Technology gap $/$ Potential yield $\times 100$

Details of Sahabhagidhan 
Sahbhagi Dhan (IR74371-70-1-1) is a conventionally bred, drought-tolerant rice variety identified in 2009 by the Central Variety Release Committee (CVRC) and released for cultivation in India, in 2010. It was introduced under direct seeded upland conditions for the states of Odisha and Chhattisgarh as well as Jharkhand and transplanted lowland conditions in the state of Tamil Nadu. The same cultivar has also been released in Bangladesh (as 'BRRI Dhan 56') and in Nepal (as 'Sookha Dhan 3') (Mandal et al. 2009; Dar et al. 2012; Dobermann 2012; Anantha et al. 2016; ). Under normal conditions, Sahbhagi Dhan produces 4-5 tonnes per hectare, whereas other varieties yield about 2.5 tonnes; under severe drought conditions, it produces 1-2 tonnes per hectare, while other high-yielding varieties produce nothing at all. With respect to irrigation, it requires two irrigations compared to the four required by other, traditional varieties, such as Sarju 55 and Sambha Mahsuri. The reduced irrigation needs allows farmers to save up to $\$ 60$ per crop. Sahbhagi Dhan is an early maturing variety that is ready after 105 days, as compared to the usual 120-150 days for other medium and long-duration varieties. This allows farmers to plant the next crop earlier (usually a rabi crop such as wheat), which in turn gives them enough time to plant three crops in a year. Moreover, Sahbhagi Dhan produces a higher straw yield, both in terms of quantity and quality (it is also reported that buffaloes like the Sahbhagi Dhan straw more than other straw, which is attributed to its particular softness) (Mandal et al. 2009; Anantha et al. 2016). It is, in short, a successful breed; but it is also rather unusual.

Instead, this particular variety was developed by a group of scientists, between 1997 and 2009, through a joint research collaboration between the International Rice Research Institute (IRRI) and various other Indian institutions, referred to here as the 'research community'.

The name 'Sahbhagi Dhan' comes from the Hindi word 'sahbhagi', which means 'cooperation', this name being chosen precisely because the variety was developed through the collaborative efforts of several institutions, thus already pointing to a common effort. 3 The development of Sahbhagi Dhan was initiated at IRRI in 1997, by French rice breeder Brigitte Courtois under the Upland Rice Research Consortium (URRC). Headed by IRRI, and partnered by NARS an institution in Indonesia, the Philippines, Thailand and India, URRC was in existence between 1991 and 1999. Courtois had made a cross between two south-east Asian rice varieties, IR5541-04 (South East Asian Indica) and WayRarem (Tropical Japonica), of which the former became the donor for drought tolerance. Then, from her base at an upland rice site in Siniloan, in the Philippines, near IRRI's headquarters in Los Banos, Courtois pedigree selected a new line, IR74371-70-1, for upland rice (Dobermann 2012).

\section{RESULTS AND DISCUSSIONS}

In Table 1 the major differences were observed between demonstration package and farmer's practices are regarding recommended varieties, seed treatment, method of sowing, fertilizer dose, method of fertilizer application, weed management and plant protection measures. Table 1 shows that under the demonstrated plot only recommended varieties, seed treating culture, herbicide and plant protection chemicals were given to farmer by the KVK and other practices were timely performed by the farmer itself under supervision of KVK scientist

The experimental findings obtained from the present study have been discussed in following heads:

\section{Yield attributes}


Analysis of pooled data(Table 2 indicated that higher plant height $(85.4 \mathrm{~cm})$, higher tillers plant1 (17.4), Effective tillers plant-1 (12.1) were recorded in Sahabhagi dhan where as lower was observed in local check Khandagiri attributing to their genetic variability, varietal difference and environmental adaptability. The differential response of tillering in the genotype could be attributed to its genetic potentiality. These results are in agreement with Sarker at el . (2013) and Mondal et al.(2005). Similarly The longer panicle $(21.9 \mathrm{~cm})$ and higher panicles $\mathrm{m}-2(208.6$.) No of filled grains per panicle (108.2)were produced in Sahabhagi dhan.

\section{Yield :}

The poolede data of Table 3 clearly indicate that Sahabhagidhan recorded grain yield 32.9 q ha- 1 which was 30.5 per cent higher yield than local check Khandagiri.(25.2q/ha) .This may be attributed to high vegetative biomass production, large panicles and high tillering capacity in some cases (C.R.R.I, 2013). The trend of straw yields of two varieties was similar with grain yields. Sahabhagi dhan recorded the higher straw yield (36.64q ha-1) with harvest index(47.4 $\%$ ) in comparison to Khandagiri(IRRI, 2013). The grain to straw ratio found to be higher(0.90) in Sahabhagidhan as compared to farmer practice Khandagiri. These results are in conformity with Tripathi at el. (2013). Thus, the FLD might have a positive impact on farming community in the district over local check. Similar results were also reported by Mondal et al. (2005) in rice crops. The results clearly indicate the positive effects of FLDs over the existing practices toward enhancing the yield of rice.

\section{Economics:}

The comparative profitability of rice cultivation with adoption of improved technology and farmers practices hasbeen presented in Table 3. The adoption of improved technology under FLDs recorded higher average gross returns(Rs 50029./ha), net returns (Rs 15773./ha) and B: C ratio (1.46) compared to farmers practice where gross returns(Rs 38512./ha), net returns (Rs 6147./ha) and B: C ratio (1.19). This fluctuating income trend was obtained due to variable price of rice and improper marketing system. These results are in conformity with the findings of Katare et al. (2011). Mitra et al, 2014 also reported the advantages of growing newly introduced variety over the traditional with higher return, the variation in net return and benefit-cost ratio may be attributed to the variation in the price of agri inputs and produce. These finding are also similar with the findings of Nirmala et al. (2012).

\section{CONCLUSION}

The cultivation of paddy Sahabhagi dhan was found to be more productive and can replace the local check since it fits to the existing farming situation for higher productivity and income and also it had been appreciated by the farmers due to its drought tolerance and higher tillering capacity. The productivity gain under FLD over farmer's practices created awareness and motivated the other farmers to adopt improved production technology of paddy in the district. Favourable benefit cost ratio itself explanatory of economic viability of the demonstration and convinced the farmers for adoption of intervention imparted. Both from the view point of crop 
intensification drive as well as climate change, there is a need to have rice varieties which could mature early without much penalty on yield. Growing short duration varieties of rice has other advantages like fitting other crops in between. It has been reported that, adoption of short duration rice varieties is one of the strategies to mitigate emission of methane and nitrous oxide which are greenhouse gases. Since, rice crop is said to be one of the major contributing factors to global warming, growing short duration varieties is one way of reducing such emissions Short duration varieties would also reduce exposure of crops to pests such as wild animals thereby reducing probability of crop damage due to shortened cropping period. Thus, more emphasis must be given on the development and release of short maturity varieties.

\section{ACKNOWLEDGEMENT:}

The authors are thankful to the Zonal Project Director, Zone-VII, Jabalpur (ICAR) for providing financial assistance towards organizing front line demonstrations.

\section{REFERENCES}

Anantha, M. S, Patel, D, Quintana, M, Swain, P, Dwivedi, J. L, Torres, R. O, Verulkar, S. B, Variar, M, Mandal, N. P, Kumar, A and Henry, A (2016). Trait Combinations that Improve Rice Yield under Drought: Sahbhagi Dhan and New Drought-Tolerant Varieties in South Asia. Crop Science 56(1): 408421, DOI: https://doi.org/10.2135/cropsci2015.06.0344

Bagchi, B.D., R. Bardhan, W.H. Jaim, and M. Hossain. 2012.Diversity, Spatial distribution and the process of adoption of improved rice varieties in West Bengal. Page 161-214

CRRI.2013. Krishi Vigyan Kendras: Front line demonstration. C.R.R.I Annual Report, 2012-13. pp. 111

Dar, M. H, Singh, S, Zaidi, N. W and Shukla, S (2012). Sahbhagi Dhan: Science's Answer to Drought Problems. STRASA News 5(3-4): 1-3.

De Datta, S.K.1981. Principles and practices of Rice production.A Wiley-Interscience publications, United States of America. 640p Food and Agriculture Organization. 2014. A regional rice strategy for sustainable food security in Asia and the Pacific. Final edition.Food and Agriculture Organization of the United NationsRegional Office for Asia and the Pacific. Bangkok, Thailand.38p

Dobermann, A (2012). Transformative Technologies, Retrieved from http://irri.org/blogs/achimdobermann-s-blog/transformative-technologies

Hasan, E. 2014.Proposing mitigation strategies for reducing the impact of rice cultivation on climate change in Egypt.National Water Research Centre. Egypt. Science Direct. Water science 27: 69-77 
Intergovernmental Panel on Climate Change. 2007. Climate change 2007. Synthesis Report.An assessment of the intergovernmental Panel on Climate Change. www.ipcc.ch/meetings/ar4workshopsexpress-meetings/uncertainty-guidancenote-pdf (accessed April 2015)

Mandal, N, Shukla, V. D, Variar, M and Kumar, A (2009). Drought-tolerant Variety Sahbhagi Dhan Released for Cultivation in India. STRASA News 2(4): 11-12.

Mitra, B.,Mookherjee, S. and Biswas.S.2014. Promotion of short duration rice variety Gotra Bidhan-1(IET 17430) through front line demonstrations in terai region of West Bengal. Journal of Crop and Weed.10(1):111-114.

Mondal, M.M.A, Islam, A.F.M.S. and Siddique, M.A. 2005. Performance of 11 modern transplant aman cultivar in the northern region of Bangladesh. Bangladesh J. Crop Sci. 16: 2329.

Nirmala, B., Vasudev, N., and Suhasini, K..2012.Acomparision of economic potential of HYVs Hybrid rice cultivation in Ambedkar nagar district of Uttar pradesh. World Journal of Agronomy.1(1):07-10.

Tripathi, K., Pandey, J. and Saxsena, A.2013.Performance of local , improved and hybrid rice varieties in district Rewa,(M.P), India. International Journal of Pharmacy \& life Science.4(12):3205-3208.

Wassmann, R., et al. 2009. Regional Vulnerability of Climate change Impacts on Asian Rice production and scope for adaption. Advances in Agronomy, International Rice Research 103 Institute. Los Banos, Philippines 22: 91-133. 


\section{International Journal of Agriculture, Environment and Bioresearch}

Vol. 4, No. 06; 2019

ISSN: $2456-8643$

Table.1: Comparison between frontline demonstrations and farmer practices

\begin{tabular}{|l|l|l|l|}
\hline SN. No & Particulars & Existing Farmer practices & $\begin{array}{l}\text { Improved Practices on } \\
\text { Demonstration }\end{array}$ \\
\hline 1 & Variety & Khandagiri & Sahabhagidhan \\
\hline 2 & Time of Sowing & $3^{\text {rd }}$ week of July & $2^{\text {nd }}$ week of July \\
\hline 3 & Seed rate & $50 \mathrm{~kg} / \mathrm{ha}$ & Line transplanting \\
\hline 4 & Seed treatment & No seed treatment & $25 \mathrm{~kg} / \mathrm{ha}$ \\
\hline 5 & Fertilizer dose & Imbalanced use of fertilizer & $\begin{array}{l}\text { Seed treatment with } \\
\text { Bavistin }\end{array}$ \\
\hline 6 & Weed management & No use of herbicide & $\begin{array}{l}\text { Hand weeding \& Use of } \\
\text { herbicide }\end{array}$ \\
\hline 7 & Plant Protection & $\begin{array}{l}\text { Injudicious use of plant protection } \\
\text { chemicals }\end{array}$ & $\begin{array}{l}\text { Need base } \\
\text { protection measures }\end{array}$ \\
\hline
\end{tabular}

Table 2: Effect of different practices on growth and growth contributing characters of rice variety Sahabhagidhan through front line demonstration

\begin{tabular}{|l|l|l|l|l|l|l|}
\hline Practices & $\begin{array}{l}\text { Plant } \\
\text { height }(\mathrm{cm})\end{array}$ & $\begin{array}{l}\text { No of } \\
\text { tillers/plant }\end{array}$ & $\begin{array}{l}\text { No offective } \\
\text { tillers/plant }\end{array}$ & $\begin{array}{l}\text { Length of } \\
\text { panicle(cm) }\end{array}$ & $\begin{array}{l}\text { No of filled } \\
\text { panicles/m2 }\end{array}$ & $\begin{array}{l}\text { No of grains/panicle } \\
\text { grang }\end{array}$ \\
\hline Sahabhagidhan & 85.4 & 17.4 & 12.1 & 21.9 & 208.6 & 108.2 \\
\hline Khandagiri & 83.8 & 10.4 & 7.3 & 20.7 & 192.3 & 103.8 \\
\hline
\end{tabular}


International Journal of Agriculture, Environment and Bioresearch

Vol. 4, No. 06; 2019

ISSN: $2456-8643$

Table 3: Cost of cultivation, gross return, net return and B:C ratio as affected by front line demonstration

\begin{tabular}{|l|l|l|l|l|l|l|l|l|}
\hline Practices & $\begin{array}{l}\text { Grain } \\
\text { Yield(q/ha) }\end{array}$ & $\begin{array}{l}\text { Straw } \\
\text { yield(q/ha) }\end{array}$ & $\begin{array}{l}\text { Harvest } \\
\text { Index }\end{array}$ & $\begin{array}{l}\text { Grain: } \\
\text { straw } \\
\text { ratio }\end{array}$ & $\begin{array}{l}\text { Cost of } \\
\text { cultivation }\end{array}$ & $\begin{array}{l}\text { Gross } \\
\text { return }\end{array}$ & $\begin{array}{l}\text { Net } \\
\text { return }\end{array}$ & $\begin{array}{l}\text { Benefit } \\
\text { cost ratio }\end{array}$ \\
\hline Sahabhagidhan & 32.9 & 36.4 & 47.4 & 0.90 & 34256 & 50029 & 15773 & 1.46 \\
\hline Khandagiri & 25.2 & 29.8 & 45.8 & 0.84 & 32365 & 38512 & 6147 & 1.19 \\
\hline
\end{tabular}

